\title{
EVALUATION OF A METHOD TO CALCULATE THE SUM-OF-FRACTIONS FOR MULTIPLE RADIONUCLIDES THAT USES AQUIFER CONCENTRATIONS OF RADIONUCLIDES THAT CHANGE WITH RESPECT TO TIME
}

Prepared by:

Leonard B. Collard

September 30, 2002

Rev. 0

Westinghouse Savannah River Company

Savannah River Site

Aiken, SC 29808

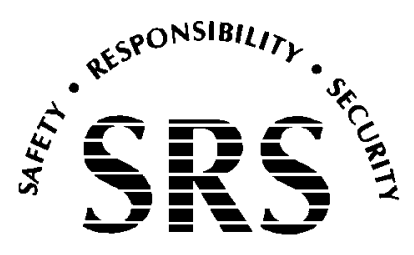


This document was prepared in conjunction with work accomplished under Contract No. DE-AC09-96SR18500 with the U. S. Department of Energy.

\section{DISCLAIMER}

This report was prepared as an account of work sponsored by an agency of the United States Government. Neither the United States Government nor any agency thereof, nor any of their employees, makes any warranty, express or implied, or assumes any legal liability or responsibility for the accuracy, completeness, or usefulness of any information, apparatus, product or process disclosed, or represents that its use would not infringe privately owned rights. Reference herein to any specific commercial product, process or service by trade name, trademark, manufacturer, or otherwise does not necessarily constitute or imply its endorsement, recommendation, or favoring by the United States Government or any agency thereof. The views and opinions of authors expressed herein do not necessarily state or reflect those of the United States Government or any agency thereof.

This report has been reproduced directly from the best available copy.

Available for sale to the public, in paper, from: U.S. Department of Commerce, National Technical Information Service, 5285 Port Royal Road, Springfield, VA 22161, phone: (800) 553-6847, fax: (703) 605-6900

email: orders@ntis.fedworld.gov

online ordering: http://www.ntis.gov/help/index.asp

Available electronically at http://www.osti.gov/bridge

Available for a processing fee to U.S. Department of Energy and its contractors, in paper, from: U.S. Department of Energy, Office of Scientific and Technical Information, P.O. Box 62, Oak Ridge, TN 37831-0062,

phone: (865)576-8401,

fax: (865)576-5728

email: $\underline{\text { reports@ adonis.osti.gov }}$ 
ii

WSRC-TR-2002-00430

REVIEWS AND APPROVALS

Author

$\frac{\text { D. H. Col land }}{9 / 26 / 02}$

Design Check

$9 / 26 / 02$

G.P. Flack, Geo-Modeling

Date

E.L. Wilhite, Waste Processing Technology

Date (per Manual E7, Procedure 2.40)

SRTC Approvals/Review

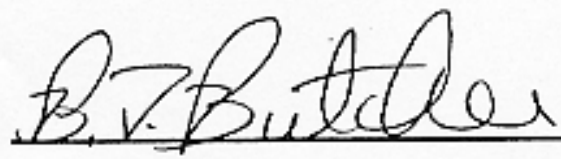

$9 / 30 / 02$

B.T. Butcher, Level 4 Manager, Waste Processing Technology

Date

EStrous

W.E. Stevens, Level 3 Manager, Waste Processing Technology

$9 / 30 / 02$

Solid Waste Division Approval

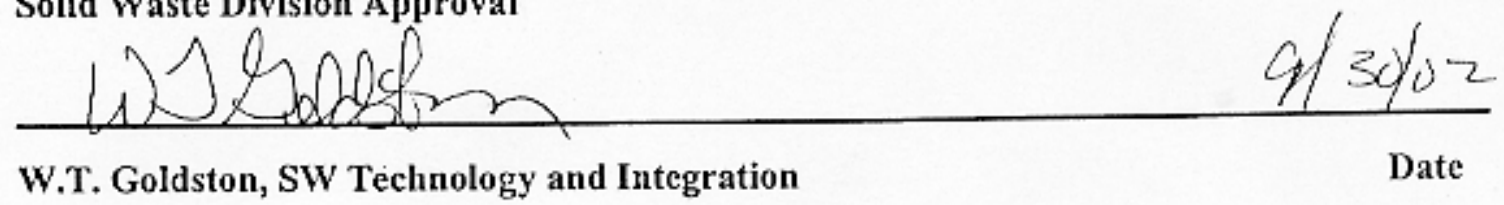

Rev. 0

September 30,2002 


\section{TABLE OF CONTENTS}

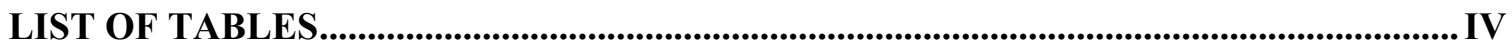

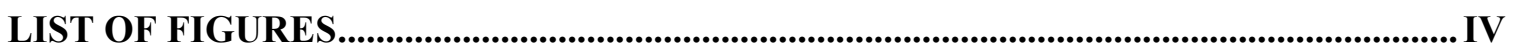

LIST OF ACRONYMS AND ABBREVIATIONS .....................................................IV

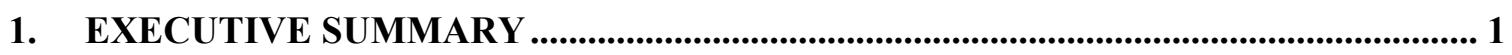

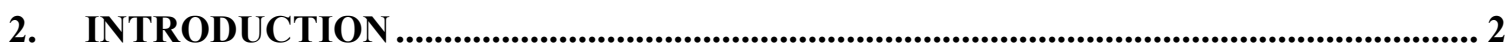

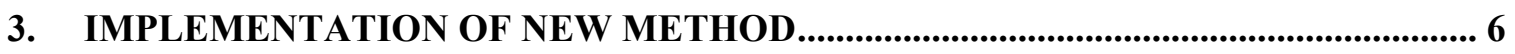

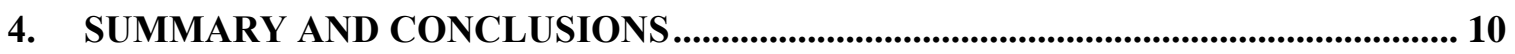

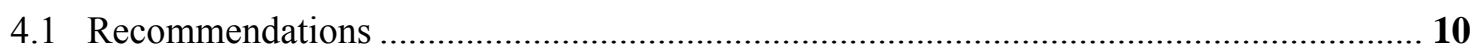

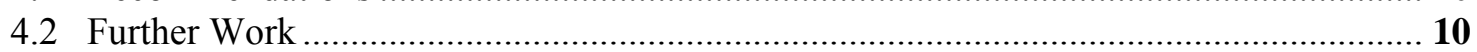

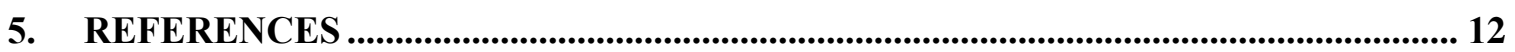

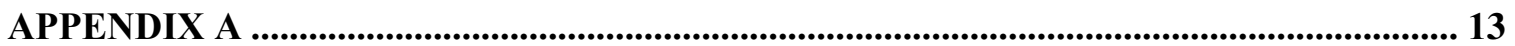




\section{LIST OF TABLES}

Table 1. SOF for example with current method ............................................................ 2

Table 2. SOF for example with new method .................................................................... 2

Table 3. Inventory limit for example aquifer scenario with current method ........................... 3

Table 4. Inventory limit for example aquifer sub-scenarios with new method........................ 4

Table 5 SOF for example with new method using aquifer sub-scenarios .............................. 4

Table 6. Major Contributors to the SOF for First Set of Slit Trenches ................................... 6

Table 7. Aquifer Concentrations by Radionuclide and Time Interval for Slit Trenches ...... 7

Table 8. Inventory Limit by Radionuclide and Scenario for First Set of Slit Trenches using

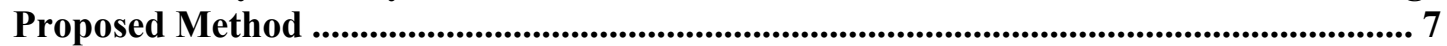

Table 9. Fractions and SOF by Scenario for First Set of Slit Trenches using Proposed

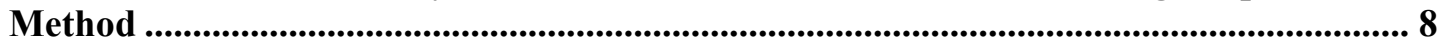

Table 10. Intermediate Level Vault Inventories and Sum-Of-Fractions................................9

Table 11. Important Fractions and SOF from Computer Program for Intermediate Level Vault with Proposed Method .................................................................................................................. 9

\section{LIST OF FIGURES}

Figure 1. Plot of hypothetical aquifer concentrations for example with one time slice ......... 3

Figure 2. Plot hypothetical of aquifer concentrations for example with two time slices......... 4

Figure 3. Plot of non-intersecting hypothetical aquifer concentrations for example with two

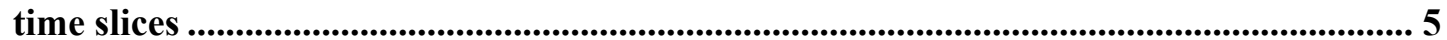

Figure 4. Dialog Box for TimeSOF Computer Program that Calculates Timed SOF ............ 8

\section{LIST OF ACRONYMS AND ABBREVIATIONS}

$\begin{array}{ll}\mu \mathbf{C i} & \text { microcuries } \\ \mathbf{C i} & \text { curie } \\ \text { DOE } & \text { U.S. Department of Energy } \\ \mathbf{E} & \text { exponential notation }\left(\text { e.g., } 5 \mathrm{E}-10=5 \times 10^{-10}=0.0000000005\right) \\ \mathbf{E R} & \text { Environmental Restoration } \\ \mathbf{E T F} & \text { Effluent Treatment Facility } \\ \mathbf{f t} & \text { feet } \\ \mathbf{g} & \text { gram } \\ \mathbf{K}_{\mathbf{d}} & \text { sorption coefficient } \\ \mathbf{L} & \text { liters } \\ \text { Log } & \text { logarithm } \\ \mathbf{m} & \text { meters } \\ \text { MCL } & \text { maximum contaminant level } \\ \text { ml } & \text { milliliters } \\ \text { PA } & \text { performance assessment } \\ \text { pCi } & \text { picocuries } \\ \text { SA } & \text { special analysis } \\ \text { U.S. } & \text { United States } \\ \text { WSRC } & \text { Westinghouse Savannah River Company } \\ \text { yr } & \text { year }\end{array}$




\section{EXECUTIVE SUMMARY}

This report evaluates a new method to calculate the sum-of-fractions (SOF) for multiple radionuclides. The purpose of this report is to determine the potential benefits of the new method for the first set of five slit trenches. Actual data were employed, although they are not up-to-date because of changing inventory levels during report preparation.

The current method for calculating the SOF relies on the minimum inventory limit established for any scenario - residential, agricultural, air, radon, post-drilling, groundwater (aquifer). The new method (explained with an example in Section 2) calculates a separate SOF for each scenario and selects the maximum SOF as the replacement for the SOF calculated by the current method.

Furthermore, multiple SOFs are calculated for the aquifer scenario. Aquifer concentrations are sliced into multiple time intervals producing aquifer sub-scenarios, each with its own local peak concentration. Each aquifer sub-scenario is treated like the aquifer scenario - a single peak aquifer concentration is selected to calculate the inventory limit for that aquifer sub-scenario. The maximum SOF from among all the aquifer sub-scenario SOFs is selected to replace the aquifer scenario SOF. For this initial evaluation, aquifer concentrations were conveniently separated into three time intervals as follows:

- $0-100$ years

- 101-1000 years

- 1001-10,000 years.

This method initially was applied to the first set of five slit trenches for the six radionuclides that contributed more than $96 \%$ to the SOF. The proposed method reduced the SOF by about $7 \%$. However, the proposed method has the potential to allow much more contamination to be disposed versus the current method, because waste that does not affect the limiting scenario (see Section 2) will not change the SOF.

The current work extends the initial scope by developing a computer program to perform the calculations for all radionuclides listed in the inventory. Available data for the Intermediate Level Vault (ILV) were input to the program for testing. Using inventories from April 24, 2002 (Sink, 2002), the proposed method calculated a SOF of 0.168 , a reduction of about 50 percent from the current SOF of 0.337 . 


\section{INTRODUCTION}

This report evaluates a new method to calculate the sum-of-fractions (SOF) for multiple radionuclides. The new method incorporates the fact that aquifer concentrations of radionuclides change with respect to time. Furthermore, this report extends beyond the initial scope by calculating separate SOFs for each scenario. An example of applying the current method and the new method follows.

Assume that only two radionuclides contribute to the SOF, Radionuclide 1 and Radionuclide 2. Further, assume that only two scenarios are applicable, the Residential Scenario and a drinking water scenario, the Aquifer Scenario. The current method selects the lowest inventory limit from all the scenarios and the SOF is calculated on that basis in Table 1.

On the other hand, each scenario is generally independent of the other scenarios (e.g., the intruder during a residential scenario at 100 years is not the same intruder during an agricultural scenario at 700 years). If two scenarios are independent of each other, then the SOF can be calculated for each scenario. The maximum scenario SOF becomes the SOF for the new method, as shown in Table 2. The SOF was reduced from 0.83 to 0.75 by isolating the scenarios.

Table 1. SOF for example with current method

\begin{tabular}{|c|c|c|c|c|c|}
\hline Radionuclide & $\begin{array}{l}\text { Inventory } \\
\text { (Ci) }\end{array}$ & $\begin{array}{l}\text { Resident } \\
\text { Limit } \\
\text { (Ci) }\end{array}$ & $\begin{array}{l}\text { Aquifer } \\
\text { Limit } \\
\text { (Ci) }\end{array}$ & $\begin{array}{l}\text { Current } \\
\text { Method } \\
\text { Limit } \\
\text { (Ci) }\end{array}$ & $\begin{array}{l}\text { Current } \\
\text { Method } \\
\text { Fraction }\end{array}$ \\
\hline Radionuclide 1 & 1 & 3 & 4 & 3 & 0.33 \\
\hline Radionuclide 2 & 1 & 4 & 2 & 2 & 0.50 \\
\hline \multicolumn{5}{|c|}{ Sum-of-Fractions } & 0.83 \\
\hline
\end{tabular}

Table 2. SOF for example with new method

\begin{tabular}{lllllll}
\hline & & & & & & New \\
Radionuclide & $\begin{array}{l}\text { Resident } \\
\text { Inventory Limit } \\
(\mathrm{Ci})\end{array}$ & $\begin{array}{l}\text { Aquifer } \\
\text { Limit }\end{array}$ & $\begin{array}{l}\text { Resident } \\
\text { (Ci) }\end{array}$ & $\begin{array}{l}\text { Aquifer } \\
\text { Fraction }\end{array}$ & $\begin{array}{l}\text { Method } \\
\text { Fraction }\end{array}$ & Fraction \\
& 1 & 3 & 4 & 0.33 & 0.25 & \\
\hline Radionuclide 1 & 1 & 4 & 2 & 0.25 & 0.50 & \\
Radionuclide 2 & 1 & & & 0.58 & 0.75 & 0.75 \\
Sum-of-Fractions & & & & & & \\
\hline
\end{tabular}

The inventory limits for the Aquifer Scenario are calculated by dividing the Maximum Contaminant Level (MCL) by the peak aquifer concentration and multiplying by the $1 \mathrm{Ci}$ inventory that was assumed for the model. A hypothetical plot of aquifer concentrations versus time for the two radionuclides is shown in Figure 1. In this figure only one time slice is considered - the entire modeling duration. Calculations of inventory limits for this figure are shown in Table 3. 


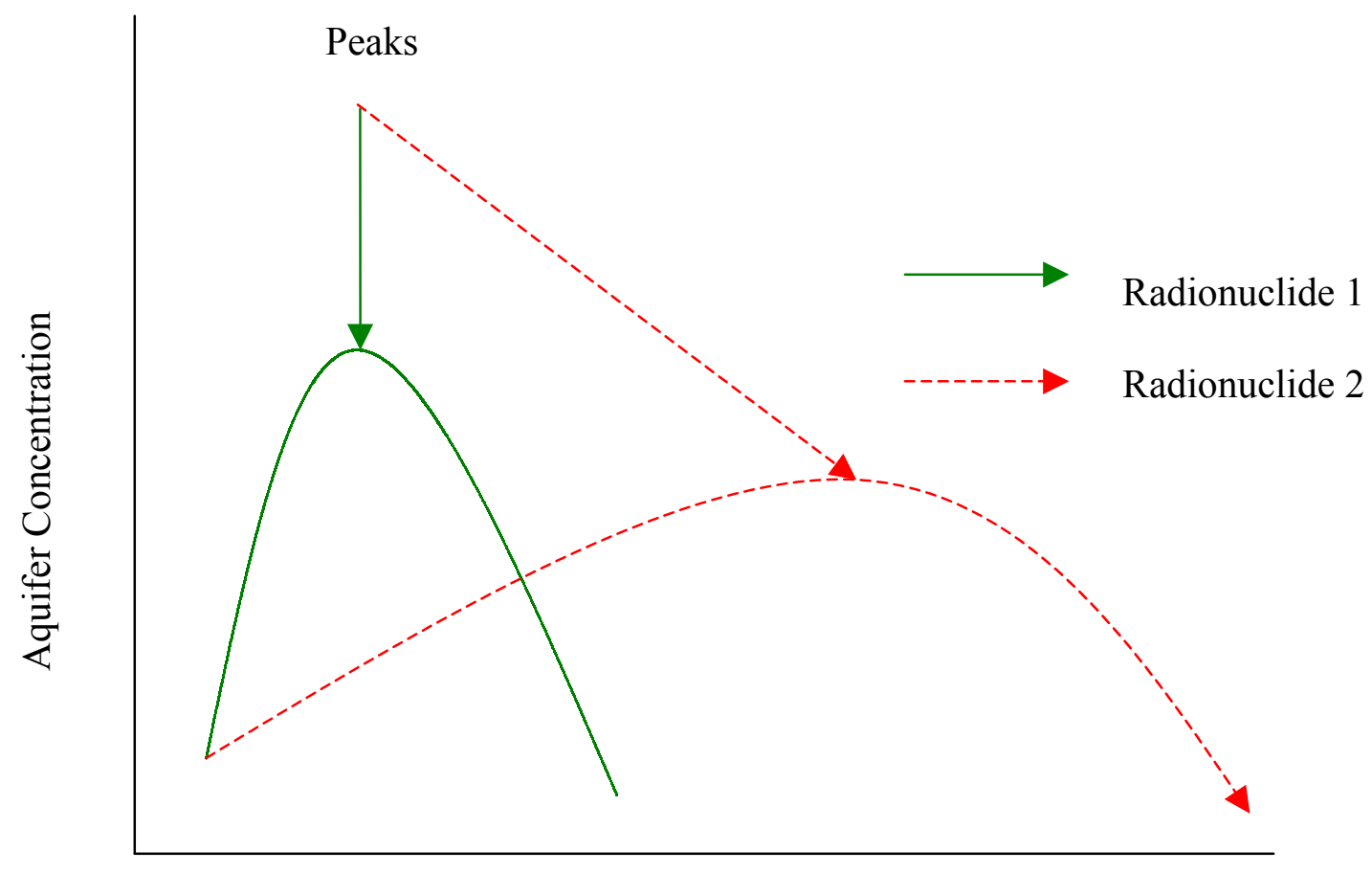

Time

Figure 1. Plot of hypothetical aquifer concentrations for example with one time slice

Table 3. Inventory limit for example aquifer scenario with current method

\begin{tabular}{lllll}
\hline & & & & $\begin{array}{l}\text { Current } \\
\text { Method } \\
\text { Aquifer }\end{array}$ \\
Radionuclide & $\begin{array}{l}\text { Inventory } \\
\text { Peak }\end{array}$ & $\begin{array}{l}\text { Concentration } \\
(\mathrm{pCi} / \mathrm{L})\end{array}$ & $\begin{array}{l}\mathrm{MCL} \\
(\mathrm{pCi} / \mathrm{L})\end{array}$ & $\begin{array}{l}\text { Limit } \\
(\mathrm{Ci})\end{array}$ \\
\hline Radionuclide 1 & 1 & 10 & 40 & 4 \\
Radionuclide 2 & 1 & 6 & 12 & 2 \\
\hline
\end{tabular}

If the time is sliced into more intervals, conservatism can be reduced as the effect of the combined peaks becomes more accurate. In Figure 2 the time is sliced into two intervals. Each time interval is considered to be a sub-scenario. Calculation of the inventory limits for the aquifer sub-scenarios is shown in Table 4. 


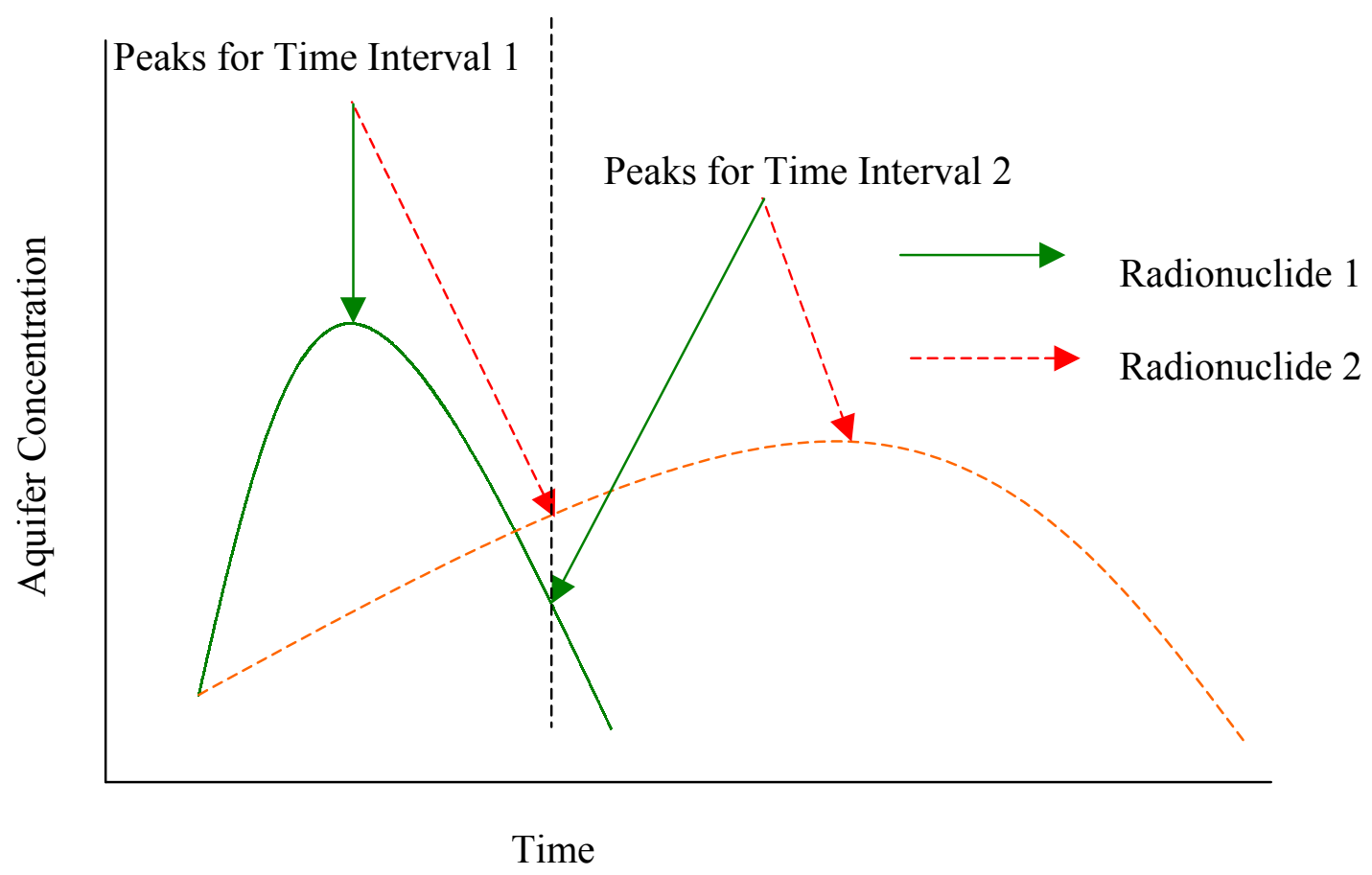

Figure 2. Plot hypothetical of aquifer concentrations for example with two time slices

Table 4. Inventory limit for example aquifer sub-scenarios with new method

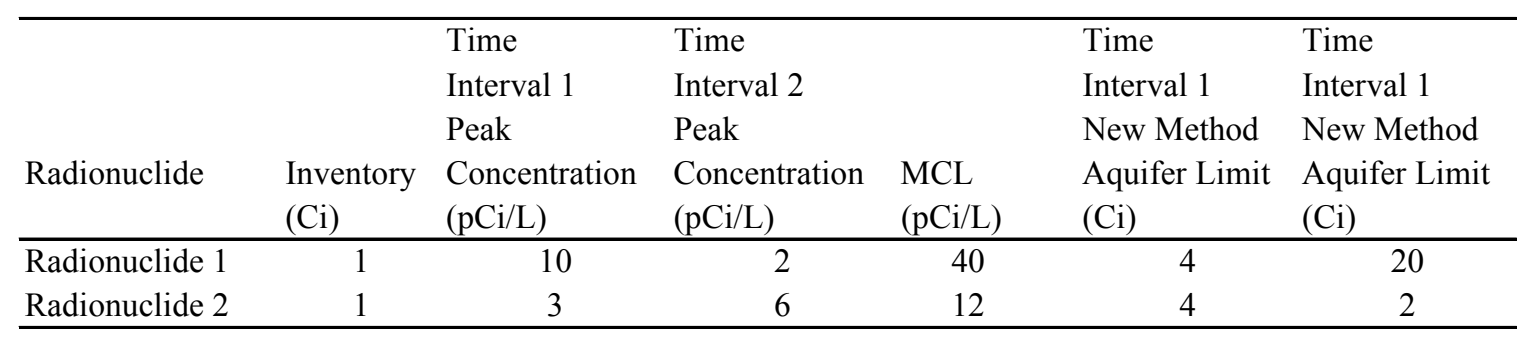

The inventory limits for the aquifer sub-scenarios replace the inventory limit for the aquifer scenario during calculation of the SOF. The SOF calculated by the new method for the example is shown in Table 5.

Table 5 SOF for example with new method using aquifer sub-scenarios

\begin{tabular}{|c|c|c|c|c|c|c|c|c|}
\hline \multirow[b]{4}{*}{ Radionuclide } & \multirow[b]{4}{*}{$\begin{array}{l}\text { Inventory } \\
\text { (Ci) }\end{array}$} & \multirow{4}{*}{$\begin{array}{l}\text { Resident } \\
\text { Limit } \\
(\mathrm{Ci})\end{array}$} & \multirow{3}{*}{$\begin{array}{l}\text { Time } \\
\text { Interval } 1 \\
\text { Aquifer }\end{array}$} & \multirow{2}{*}{$\begin{array}{l}\text { Time } \\
\text { Interval } 2\end{array}$} & \multirow{4}{*}{$\begin{array}{l}\text { Resident } \\
\text { Fraction }\end{array}$} & \multirow{4}{*}{$\begin{array}{l}\text { Time } \\
\text { Interval } 1 \\
\text { Aquifer } \\
\text { Fraction }\end{array}$} & \multirow{3}{*}{$\begin{array}{l}\text { Time } \\
\text { Interval } 2 \\
\text { Aquifer } \\
\text { Fraction }\end{array}$} & \multirow{4}{*}{$\begin{array}{l}\text { New } \\
\text { Method } \\
\text { Fraction }\end{array}$} \\
\hline & & & & & & & & \\
\hline & & & & Aquifer & & & & \\
\hline & & & $\begin{array}{l}\text { Limit } \\
\text { (Ci) }\end{array}$ & $\begin{array}{l}\text { Limit } \\
(\mathrm{Ci})\end{array}$ & & & Fraction & \\
\hline Radionuclide 1 & 1 & 3 & 4 & 20 & 0.33 & 0.25 & 0.05 & \\
\hline Radionuclide 2 & 1 & 4 & 4 & 2 & 0.25 & 0.25 & 0.50 & \\
\hline Sum-of-Fractions & & & & & 0.58 & 0.50 & 0.55 & 0.58 \\
\hline
\end{tabular}


The SOF with the current method was 0.83 . Calculations for isolated scenarios reduced the SOF to 0.75 . Calculations for slicing the aquifer results into different time intervals further reduced the SOF to 0.58 .

The maximum utility for time slicing occurs when two radionuclides exhibit concentration curves that do not intersect. An example is shown in Figure 3. If all other scenarios can be ignored and if the new method is applied, then the inventory of Radionuclide 1 can match its inventory limit and the inventory of Radionuclide 2 can match its inventory limit. Under the current method if equivalent amounts of inventory are consumed by each radionuclide, then the inventory of Radionuclide 1 can only be $1 / 2$ of its inventory limit and the inventory of Radionuclide 2 can only be $1 / 2$ of its inventory limit. In the former case of the new method, the SOF is 1.0 for each radionuclide, but those two SOFs are not additive. In the latter case of the current method the SOFs are additive, thus neither can exceed 0.5

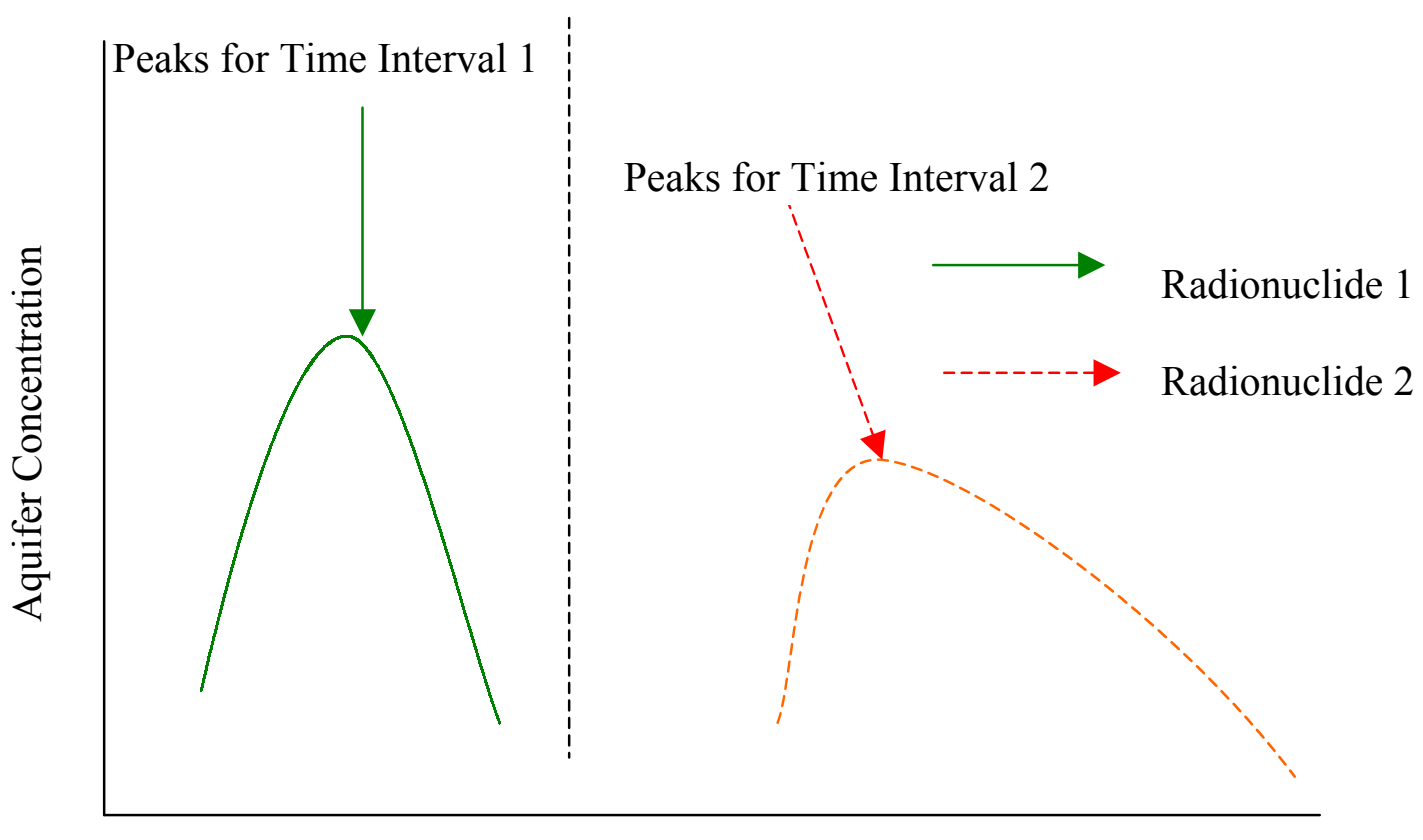

Time

Figure 3. Plot of non-intersecting hypothetical aquifer concentrations for example with two time slices

For the initial evaluation of the new method and for the sake of convenience, aquifer concentrations were separated into three time intervals as follows:

1. $0-100$ years

2. 101-1000 years

3. 1001-10,000 years.

The maximum aquifer concentration within a time interval was assumed to apply for all times in that time interval. For example, if the aquifer concentration during the second time interval (101-1000 years) ranged from $1 \mathrm{pCi} / \mathrm{L}$ to $10 \mathrm{pCi} / \mathrm{L}$, then $10 \mathrm{pCi} / \mathrm{L}$ was assumed to replace all concentrations during that time interval.

The principles of the simplified example are easily extended to include multiple radionuclides, scenarios and aquifer sub-scenarios. These extensions are discussed in the next section. 


\section{IMPLEMENTATION OF NEW METHOD}

The SOF for the new method is calculated using all radionuclides in inventory. However, for ease of discussion, the major contributors to the SOF for the first set of five slit trenches were examined. Table 6 shows the total SOF as of March 25, 2002 (Sink, 2002) and the radionuclides that contribute at least 0.01 percent (1E-4 as a fraction) to the total SOF. From this list a subset of radionuclides that contribute at least 1 percent (1E-2 as a fraction) was further evaluated. This subset contributes 0.775 as a SOF versus the total SOF of 0.801 , which is $97 \%$ of the SOF on a percentage basis.

Table 6. Major Contributors to the SOF for First Set of Slit Trenches

\begin{tabular}{|c|c|c|c|}
\hline \multirow[b]{2}{*}{ Radionuclide } & \multicolumn{3}{|l|}{ First Set of } \\
\hline & $\begin{array}{l}\text { Slit Trenches } \\
\text { Inventory } \\
\text { as of } 3 / 25 / 02 \\
\text { (Ci) }\end{array}$ & $\begin{array}{c}\text { PA Revision } \\
\text { W ith Adj. W ood } \\
\text { Lin its } \\
\text { (C i) }\end{array}$ & $\begin{array}{l}\text { Fraction } \\
\text { OfLim it }\end{array}$ \\
\hline$\overline{\mathrm{H} 3}$ & $4.35688 \mathrm{E}+00$ & $6.3 \mathrm{E}+00$ & $6.92 \mathrm{E}-01$ \\
\hline I129 & 1.43392E-05 & $5.2 \mathrm{E}-04$ & 2.76E-02 \\
\hline PU239 & 1.56353E-02 & 8.8E-01 & 1.78E-02 \\
\hline I129J & 2.46160E-05 & 1.6E-03 & 1.53E-02 \\
\hline NP237 & $5.58829 \mathrm{E}-04$ & $4.8 \mathrm{E}-02$ & 1.16E-02 \\
\hline U 238 & $5.67228 \mathrm{E}-02$ & $5.0 \mathrm{E}+00$ & $1.13 \mathrm{E}-02$ \\
\hline \multicolumn{3}{|c|}{ Sum -ofrraction for above subset } & $7.75 \mathrm{E}-01$ \\
\hline TC99 & 3.64022E-03 & $5.5 \mathrm{E}-01$ & $6.62 \mathrm{E}-03$ \\
\hline SR90 & $3.05676 \mathrm{E}+00$ & $5.2 E+02$ & $5.88 \mathrm{E}-03$ \\
\hline PU240 & 4.76679E-03 & $1.1 \mathrm{E}+00$ & 4.33E-03 \\
\hline C14 & 6.35895E-03 & $2.7 E+00$ & 2.36E-03 \\
\hline PU242 & 3.46535E-05 & 1.6E-02 & 2.17E-03 \\
\hline TH232 & $2.34134 \mathrm{E}-03$ & $1.3 \mathrm{E}+00$ & 1.80E-03 \\
\hline U 236 & 1.74287E-03 & $2.0 \mathrm{E}+00$ & $8.71 \mathrm{E}-04$ \\
\hline PU238 & 1.70087E-01 & $2.6 E+02$ & $6.54 \mathrm{E}-04$ \\
\hline CS137 & $6.66725 \mathrm{E}+00$ & $2.1 \mathrm{E}+04$ & 3.17E-04 \\
\hline U234 & 3.66170E-02 & $1.8 \mathrm{E}+02$ & 2.03E-04 \\
\hline AM241 & 2.38723E-02 & $2.2 \mathrm{E}+02$ & 1.09E-04 \\
\hline \multicolumn{3}{|c|}{ Sum -of raction for above radionuclides } & $8.00 \mathrm{E}-01$ \\
\hline \multicolumn{3}{|c|}{ Sum -offraction for all radionuclides } & $8.01 \mathrm{E}-01$ \\
\hline
\end{tabular}

To determine the inventory limit for each aquifer's sub-scenario, the aquifer concentrations in modeling output files were examined. The peak aquifer concentrations for each time interval are provided in Table 7. 
Table 7. Aquifer Concentrations by Radionuclide and Time Interval for Slit Trenches

\begin{tabular}{lrrr}
\hline & \multicolumn{3}{c}{ Peak Aquifer Concentration (pCi/L) } \\
Radionuclide & $0-100$ years & $101-1000$ years & $1001-10,000$ years \\
\hline H-3 & 1587 & 8 & $0^{1}$ \\
I-129 & 477 & 139 & $0^{1}$ \\
Pu-239 & $0^{1}$ & $0^{1}$ & 4.2 \\
I-129J ${ }^{2}$ & 9.9 & 155.7 & 0 \\
(F-Area filtercake) & & & \\
Np-237 & $2.8 \mathrm{E}-2$ & 92.3 & $0^{1}$ \\
U-238 & $0^{1}$ & 12.0 & 14.1 \\
\hline
\end{tabular}

${ }^{1}$ No value in data files because finding global peak value was emphasized

${ }^{2}$ Used I-129 with $\mathrm{K}_{\mathrm{d}}$ of $50 \mathrm{ml} / \mathrm{g}$ as a surrogate for $\mathrm{K}_{\mathrm{d}}$ of $56.7 \mathrm{ml} / \mathrm{g}$ (Collard, 2001)

(Table values are explicit values from modeling output files without linear interpolation)

An alternative method to calculate the inventory limit $\left(\operatorname{Inv}_{\mathrm{i}}\right)$ for the ith specific time interval is

$\operatorname{Inv}_{\mathrm{i}}=\operatorname{Inv}_{\mathrm{PA}} \mathrm{x} \operatorname{Maximum}(\mathrm{C}) / \operatorname{peak} \mathrm{C}_{\mathrm{i}}$

where

Inv $_{\mathrm{PA}}$ is the inventory limit from the Performance Assessment (PA, McDowell-Boyer, et al., 2000), revised for the effect of wood products (Cook, 2000). These limits were selected to match those provided in Table 6.

Maximum $\mathrm{C}$ is the maximum concentration over all time intervals, and

Peak $\mathrm{C}_{\mathrm{i}}$ is the peak aquifer concentration for the ith time interval.

Inventory limits for each time interval of the aquifer sub-scenarios are provided in Table 8 . Table 8 also includes inventory limits for all other scenarios.

Table 8. Inventory Limit by Radionuclide and Scenario for First Set of Slit Trenches using Proposed Method

\begin{tabular}{|c|c|c|c|c|c|c|c|}
\hline \multirow[b]{2}{*}{ Radionuclide } & \multicolumn{7}{|c|}{ Inventory Limit for 5 Slit Trenches $(\mathrm{Ci})^{1}$} \\
\hline & Air & $\begin{array}{l}\text { Post- } \\
\text { Drill }\end{array}$ & $\begin{array}{l}\text { Res. - } \\
100 \mathrm{yr}\end{array}$ & $\begin{array}{l}\text { Ag. - } \\
700 \mathrm{yr}\end{array}$ & Aq. 1 & Aq. 2 & Aq. 3 \\
\hline H-3 & $3.2 \mathrm{E} 5$ & NA & NA & NA & $6.30 \mathrm{E}+00$ & $1.25 \mathrm{E}+03$ & NA \\
\hline $\mathrm{I}-129$ & NA & 4.4E7 & NA & NA & $5.20 \mathrm{E}-04$ & $1.78 \mathrm{E}-03$ & NA \\
\hline $\mathrm{Pu}-239$ & NA & $1.1 \mathrm{E} 3$ & NA & $3.1 \mathrm{E} 3$ & NA & NA & 8.80E-01 \\
\hline $\mathrm{I}-129 \mathrm{~J}^{2}$ & NA & 320 & NA & NA & $2.53 \mathrm{E}-02$ & $1.61 \mathrm{E}-03$ & NA \\
\hline $\mathrm{Np}-2$ & NA & 210 & & $9.1 \mathrm{E} 7$ & $3.00 \mathrm{E}+02$ & $9.10 \mathrm{E}-02$ & NA \\
\hline U-238 & NA & $4.8 \mathrm{E} 3$ & $1.9 \mathrm{E} 6$ & $1 \mathrm{E} 4$ & NA & $5.88 \mathrm{E}+00$ & $5.00 \mathrm{E}+00$ \\
\hline
\end{tabular}

${ }^{1}$ Radon is not applicable for any of the above radionuclides and no limit is listed

${ }^{2}$ F-Area filtercake with I- $129 \mathrm{~K}_{\mathrm{d}}$ of $50 \mathrm{ml} / \mathrm{g}$ used as a surrogate for $\mathrm{K}_{\mathrm{d}}$ of $56.7 \mathrm{ml} / \mathrm{g}$

(Table values from Cook, 2000.)

The inventory consumption fraction for a specific radionuclide in a specific scenario is calculated by dividing the inventory by its inventory limit for that scenario. The SOF for that scenario is 
calculated by summing the inventory consumption factors for all radionuclides. Table 9 shows the inventory consumption factors and the SOF by scenario for the most important radionuclides for the first set of slit trenches.

Table 9. Fractions and SOF by Scenario for First Set of Slit Trenches using Proposed Method

\begin{tabular}{|c|c|c|c|c|c|c|c|c|}
\hline Radionuclide & $\begin{array}{l}\text { Inv } \\
(\mathrm{Ci})\end{array}$ & $\begin{array}{c}\text { Fractions } \\
\text { Air }\end{array}$ & Drill & Res. & Ag. & Aq. 1 & Aq. 2 & Aq. 3 \\
\hline H-3 & $4.36 \mathrm{E}+00$ & $1.36 \mathrm{E}-05$ & & & & $6.92 \mathrm{E}-01$ & $3.49 \mathrm{E}-03$ & \\
\hline $\mathrm{I}-129$ & $1.43 \mathrm{E}-05$ & & $3.26 \mathrm{E}-13$ & & & $2.76 \mathrm{E}-02$ & 8.04E-03 & \\
\hline $\mathrm{Pu}-239$ & $1.56 \mathrm{E}-02$ & & $1.42 \mathrm{E}-05$ & & $5.04 \mathrm{E}-06$ & & & $1.78 \mathrm{E}-02$ \\
\hline $\mathrm{I}-129 \mathrm{~J}$ & $2.46 \mathrm{E}-05$ & & 7.69E-08 & & & $9.72 \mathrm{E}-04$ & $1.53 \mathrm{E}-02$ & \\
\hline Np-237 & $5.59 \mathrm{E}-04$ & & $2.66 \mathrm{E}-06$ & & $6.14 \mathrm{E}-12$ & $1.86 \mathrm{E}-06$ & $6.14 \mathrm{E}-03$ & \\
\hline U-238 & 5.67E-02 & & $1.18 \mathrm{E}-05$ & $2.99 \mathrm{E}-08$ & 5.67E-06 & & $9.65 \mathrm{E}-03$ & $1.13 \mathrm{E}-02$ \\
\hline \multicolumn{2}{|c|}{ SOF for above nuclides } & $1.36 \mathrm{E}-05$ & $2.88 \mathrm{E}-05$ & $2.99 \mathrm{E}-08$ & $1.07 \mathrm{E}-05$ & $7.20 \mathrm{E}-01$ & $4.26 \mathrm{E}-02$ & $2.91 \mathrm{E}-02$ \\
\hline
\end{tabular}

The aquifer sub-scenario during the first time interval produces the highest SOF of 0.720 . This results in a reduction of 0.07 (or 7 percent) from 0.775 calculated using the current method.

The second part of this evaluation was to commence development of a computer program to automate the calculations, because the proposed method introduces complexities, e.g., the number of time intervals could become quite extensive. The first phase of the computer program has been completed. The dialog box from the computer program (TimeSOF) is shown in Figure 4.

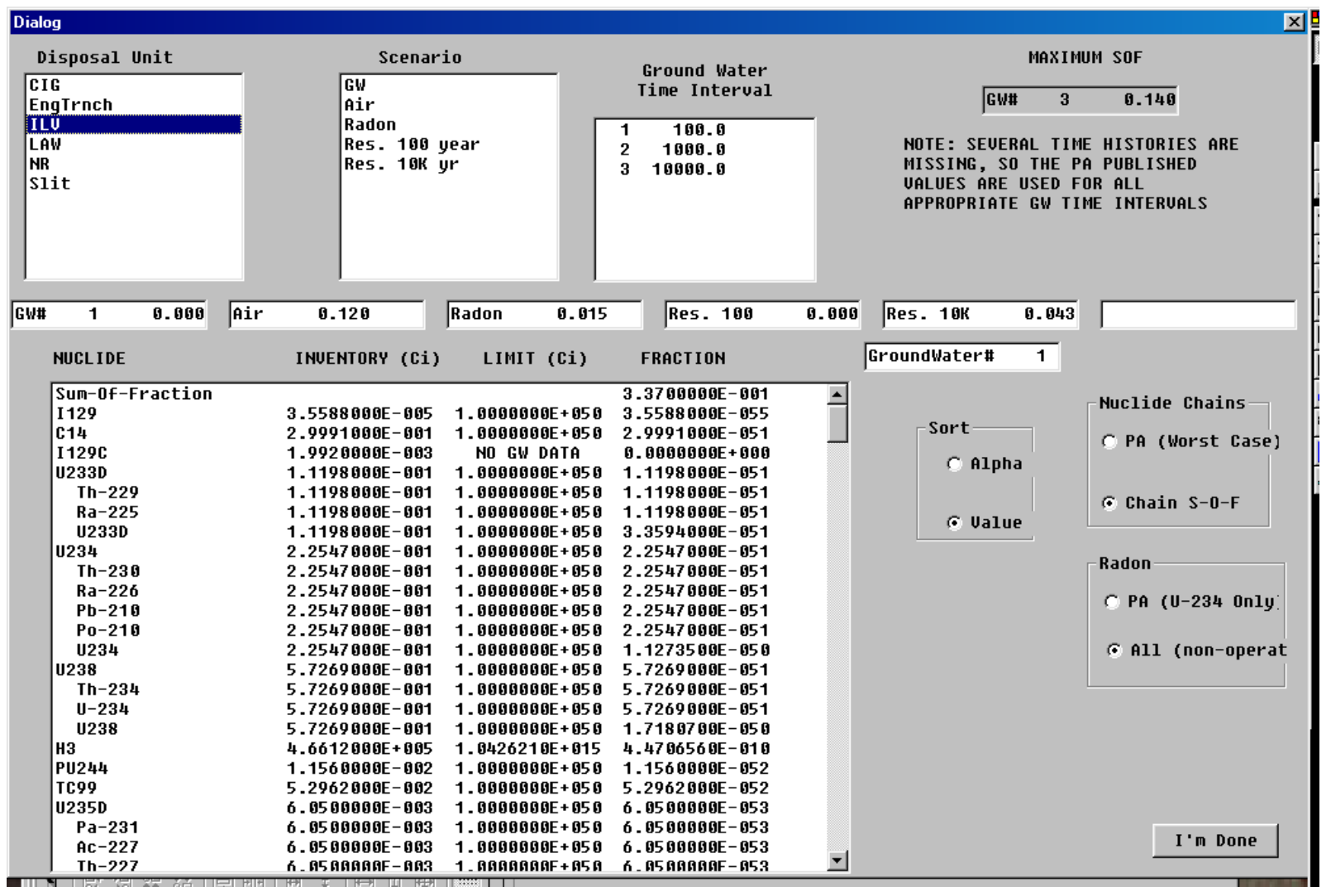

Figure 4. Dialog Box for TimeSOF Computer Program that Calculates Timed SOF 
Data from the Intermediate Level Vault were input to the database that the computer program reads. The current method for the SOF produces the results shown in Table 10 for those radionuclides that contribute $99 \%$ of the total SOF.

Table 10. Intermediate Level Vault Inventories and Sum-Of-Fractions

\begin{tabular}{|c|c|c|c|}
\hline Radionuclide & $\begin{array}{c}\text { ILV } \\
\text { Inventory } \\
\text { as of } 4 / 24 / 02 \\
(\mathrm{Ci})\end{array}$ & $\begin{array}{l}\text { Limit } \\
\text { (Ci) }\end{array}$ & $\begin{array}{c}\text { Fractio } \\
\text { n } \\
\text { of } \\
\text { Limit }\end{array}$ \\
\hline 1129 & 3.5588E-05 & $2.6 \mathrm{E}-04$ & 1.37E-01 \\
\hline C14 & 2.9991E-01 & $2.7 E+00$ & 1.11E-01 \\
\hline I129C & 1.9920E-03 & 7.1E-02 & 2.81E-02 \\
\hline U233D & 1.1198E-01 & 7.0E+00 & 1.60E-02 \\
\hline U234 & 2.2547E-01 & $1.5 E+01$ & 1.50E-02 \\
\hline U238 & 5.7269E-01 & $4.9 \mathrm{E}$ & 1.17E-02 \\
\hline $\mathrm{H} 3$ & $4.6612 E+05$ & $5.5 E+07$ & 8.47E-03 \\
\hline PU244 & 1.1560E-02 & $3.1 E+00$ & 3.73E-03 \\
\hline TC99 & 5.2962E-02 & $2.2 \mathrm{E}+01$ & 2.41E-03 \\
\hline U235D & 6.0500E-03 & $6.0 \mathrm{E}+00$ & 1.01E-03 \\
\hline SN126 & 4.8512E-04 & 7.5E-01 & 6.47E-04 \\
\hline U233 & 4.1364E-03 & 7.0E+00 & 5.91E-04 \\
\hline U235 & 2.1846E-03 & $6.0 \mathrm{E}+00$ & 3.64E-04 \\
\hline NP237 & 1.5361E-03 & $6.0 \mathrm{E}+00$ & 2.56E-04 \\
\hline CS137 & 1.5115E+02 & $6.5 E+05$ & 2.33E-04 \\
\hline \multicolumn{3}{|c|}{$\begin{array}{l}\text { Sum-of-Fraction for above } \\
\text { radionuclides }\end{array}$} & $\begin{array}{l}3.36 \mathrm{E}- \\
01\end{array}$ \\
\hline \multicolumn{3}{|c|}{ Sum-of-Fraction for all radionuclides } & $\begin{array}{l}3.37 \mathrm{E}- \\
01\end{array}$ \\
\hline
\end{tabular}

I129C is the ETF Activated Carbon Vessels

Results from the computer program for the proposed method are presented in Table 11. (Results for the ETF Activated Carbon Vessels were manually added to the computer results, because the ETF vessel information is not currently in the computer database.) The current method shows a SOF of 0.337 , while the proposed method shows a SOF of 0.168 , a reduction of about 50 percent.

Table 11. Important Fractions and SOF from Computer Program for Intermediate Level Vault with Proposed Method

\begin{tabular}{|c|c|c|c|c|c|c|c|c|}
\hline Radionuclide & $\begin{array}{l}\text { Inv } \\
\text { (Ci) }\end{array}$ & $\begin{array}{c}\text { Fractions } \\
\text { Air } \\
\end{array}$ & Radon & $\begin{array}{l}\text { Res. } \\
100 \mathrm{yr}\end{array}$ & $\begin{array}{c}\text { Res. } \\
10000 \mathrm{yr}\end{array}$ & Aq. 1 & Aq. 2 & Aq. 3 \\
\hline C-14 & $2.99910 \mathrm{E}-01$ & $1.10 \mathrm{E}-01$ & & & & & & \\
\hline U-234 & $2.25470 \mathrm{E}-01$ & & $1.50 \mathrm{E}-02$ & & & & & \\
\hline U-233D & $1.11980 \mathrm{E}-01$ & & & & $1.60 \mathrm{E}-02$ & & & \\
\hline $\mathrm{U}-238$ & $5.72690 \mathrm{E}-01$ & & & & $1.10 \mathrm{E}-02$ & & & \\
\hline $\mathrm{I}-129$ & $3.55880 \mathrm{E}-05$ & & & & & & & $1.38 \mathrm{E}-01$ \\
\hline $\mathrm{I}-129 \mathrm{C}$ & $1.99200 \mathrm{E}-03$ & & & & & & & 2.79E-02 \\
\hline \multicolumn{2}{|c|}{ SOF for above radionuclides } & $1.10 \mathrm{E}-01$ & $1.50 \mathrm{E}-02$ & $0.00 \mathrm{E}+00$ & $2.70 \mathrm{E}-02$ & $0.00 \mathrm{E}+00$ & $0.00 \mathrm{E}+00$ & $1.66 \mathrm{E}-01$ \\
\hline \multicolumn{2}{|c|}{ SOF for all radionuclides } & $1.20 \mathrm{E}-01$ & $1.50 \mathrm{E}-02$ & $1.00 \mathrm{E}-06$ & $4.30 \mathrm{E}-02$ & $4.00 \mathrm{E}-10$ & $2.00 \mathrm{E}-06$ & $1.68 \mathrm{E}-01$ \\
\hline
\end{tabular}




\section{SUMMARY AND CONCLUSIONS}

The proposed method for calculating the SOF involved two changes to the current method. First, the aquifer scenario was sliced into multiple time intervals that represent sub-scenarios. In this report, three time intervals were selected, but the number of time intervals can be increased.

The second change was that a SOF was calculated for each scenario. This change bears the intrinsic assumption that the receptor for each scenario is different. Obviously, the resident at 100 years is different than the receptor at 10,000 years. The groundwater scenario is based on the MCL, thus it is independent of the other scenarios for the purpose of calculating the SOF. The air and radon scenarios are independent by definition, not time.

The proposed method produced a SOF for the slit trenches that was only 7 percent lower than the SOF calculated with the current method. However, disposing of selected waste that has minimal impact on the SOF for the dominant scenario would allow substantially more waste to be disposed under the proposed SOF method. Meanwhile, the proposed SOF method would reduce the SOF by 50 percent for contaminants in the Intermediate Level Vault. Other disposal facilities were not evaluated because the scope of work was limited to the first set of five slit trenches.

\subsection{Recommendations}

The proposed method of calculating SOFs presents an opportunity to reduce conservatisms, generally allowing more curies of contaminants to be disposed in the same volume. Increasing allowable contaminant inventories for one disposal facility will not affect other disposal facilities, because each disposal facility has a SOF that is independent of all others.

It is recommended that the proposed method be adopted for all facilities where a substantial benefit would be achieved. Facilities that are constrained such that the entire volume could not be filled without exceeding the SOF are candidates for applying the proposed method. If a facility has no such constraint, then there is no need to use a more sophisticated method to calculate the SOF.

Solid Waste would need to implement the proposed method in WITS. WITS could include the algorithms from TimeSOF or it could access TimeSOF as an external program. Because several months will be required to modify WITS, it is recommended that the computer program that calculates the proposed method (TimeSOF) be completed independent of WITS and that its database be fully populated. TimeSOF could be independently operated for three to six months to find and fix any errors. Any recommended changes to the algorithms that calculate the SOF for aquifer slicing and isolated scenarios could be incorporated and tested before modifying WITS.

\subsection{Further Work}

If it is decided to adopt the proposed method, then the first step is to select the facilities to which the proposed method will apply. The first set of slit trenches is not operating at this time. Thus the first set of slit trenches is an ideal first candidate for full implementation, because it would provide static information for fully testing computer programs without affecting day-to-day 
operations. The second recommended candidate is the LAW Vault because it receives much attention regarding its disposal lifecycle.

The second step is to identify the radionuclides to which the proposed method will apply. For radionuclides that have little impact, their fraction of the SOF can be calculated by the current method. On the other hand, computer programs can easily accommodate all radionuclides in inventory without the bother of determining the most important contributors.

The third step is to select the number of time intervals for the aquifer model. Theoretically, the time intervals can be refined almost without limit. Selecting very small time intervals could isolate sharp peaks for two highly mobile contaminants, such as for H-3 and I-129. However, uncertainties in $\mathrm{K}_{\mathrm{d}} \mathrm{S}$ and operations could cause the peaks to overlap under real field conditions, thus the selection of time intervals should be tempered by the uncertainties involved.

Because radionuclides were analyzed to calculate the peak aquifer concentration only, some data were ignored, leading to zero values in other time intervals. The existing modeling data need to be examined to determine if more detailed modeling is required.

Some modeling output files do not exist. For these cases the peak concentration value must be used unless the model is regenerated and reexecuted.

The computer program (TimeSOF) will have options to calculate the sum-of-fractions using either the PA/SA analysis results that currently form the basis for WITS or other methods that likely will replace those results. One example would be if a new PA/SA has been issued but not yet implemented in WITS, then the user would have the option to see the sum-of-fractions using values from new PA/SA. Another example would be that for inventory limits for the groundwater pathway are established based on the most critical radionuclide in a decay chain. The user would have the option to use that method or to use a sum-of-fraction method that incorporates all members of the decay chain that were modeled. 


\section{REFERENCES}

Collard, L.B. 2000. Special analysis for Disposal of High-Concentration I-129 Waste in the LowActivity Waste Vaults at the E-Area Low-Level Waste Facility, WSRC-RP-2000-00138, Rev. 0, Westinghouse Savannah River Company, Aiken, South Carolina.

Collard, L.B. 2001. Special analysis for Disposal of High-Concentration I-129 Waste in Slit Trenches at the E-Area Low-Level Waste Facility, WSRC-TR-2001-00021, Rev. 0, Westinghouse Savannah River Company, Aiken, South Carolina.

Cook, J.R. 2000. Updated analysis of the Effect of Wood Products on Trench Disposal Limits at the E-Area Low-Level Waste Facility, WSRC-RP-2000-00523, Rev. 0, Westinghouse Savannah River Company, Aiken, South Carolina.

McDowell-Boyer, L., A.D. Yu, J.R. Cook, D.C. Kocher, E.L. Wilhite, H. Holmes-Burns, and K.E. Young. 2000. Radiological Performance Assessment for the E-Area LowLevel Waste Facility, WSRC-TR-94-218, Revision 1, Westinghouse Savannah River Company, Aiken, South Carolina, 29808.

Sink, D.F., Jr. 2002. Personal Communication, May 7. 


\section{APPENDIX A}

Copies of the design reviews are provided below. Comment resolutions are provided after the design review.

\section{Design Review from G.P. Flach}

SRT-EST-2002-00172

To: $\quad$ Tom Butcher, 773-43A

Len Collard, 773-43A

From: $\quad$ Greg Flach, 773-42A

Copy: $\quad$ Mary Harris, 773-42A

File, $773-42 \mathrm{~A}$

Date: $\quad$ September 26, 2002

Subject: Design Check of Time-Dependent Sum of Fractions Evaluation (WSRC-TR-2002-00430 draft)

A design check of "Evaluation of a method to calculate the sum-of-fractions for multiple radionuclides that uses aquifer concentrations of radionuclides that change with respect to time", WSRC-TR-2002-00430 (September 24, 2002 draft) was performed following the general guidance provided in WSRC-IM-2002-00011 and the specific instruction:

1. Check the APPROACH to make recommendations on better ways to implement the new method, e.g.,

- Ease of use of computer program

- Flexibility and robustness

- Better ways to display results

2. Check the MATHEMATICS by

- Spot checking the slit trench for 1 key radionuclide

- Spot checking the ILV for 1 key radionuclide

3. Check to ensure that the INPUTS are correct for

- the inventory and current sum-of-fractions for the major contributors

- the time slice peak concentrations for one key radionuclide

- (the base files from which these data were selected will be provided)

4. Check to ensure that the OUTPUTS are reasonable by

- Spot check the sum-of-fractions for one pathway for the slit trench

- Spot check the sum-of-fractions for one pathway for the ILV

Check that all major uncertainties that could lead to different recommendations are

presented and discussed. Mention any beneficial outputs that are not presented.

5. TRANSCRIPTION: Check to ensure that important numerical values (i.e., sums-offractions) are consistent throughout the report. If the numbers are presented at two different locations throughout the report, they should be identical, except for rounding. 
The document was checked at a level sufficient to address the 5 specific items listed above. No major technical issues were identified during the course of the review. However, a few minor corrections and comments are identified in the table below, along with suggested resolutions.

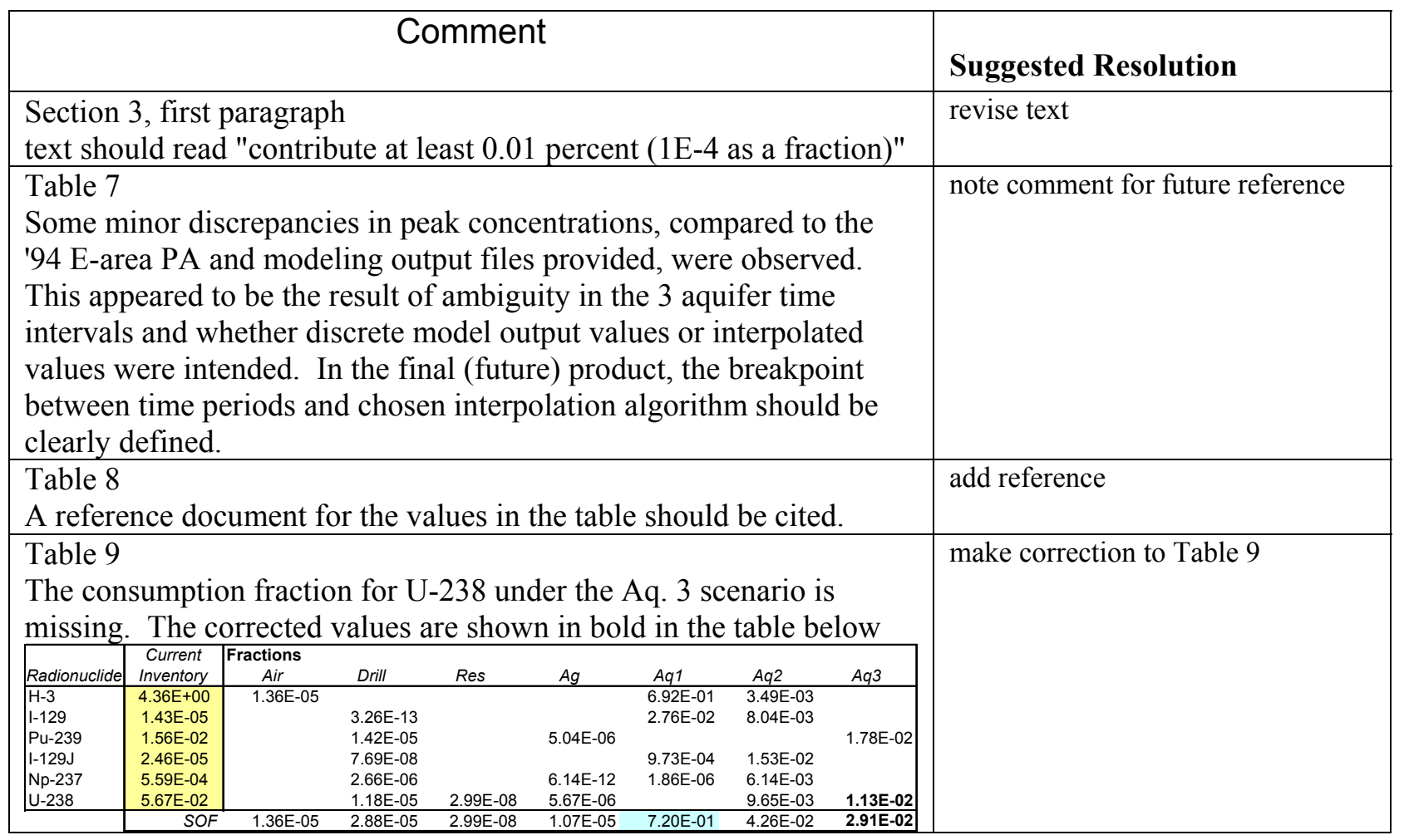

\section{Comment Resolutions for G.P. Flach}

1. The text was revised.

2. A note was added to the tables that explicit values from modeling output were used, but that interpolation was not performed.

3. A reference was added.

4. Table 9 was corrected.

\section{Design Review from E.L. Wilhite}

Len:

Per your instructions, I've conducted a design check of your document "Evaluation of a Method to Calculate the Sum-of-Fractions for Multiple Radionuclides that uses Aquifer Concentrations of Radionuclides that change with respect to time", WSRC-TR-2002-00430.

Following are my comments versus each of your instructions. My task was to "Check the APPROACH to ensure the following conditions are satisfied (this review covers ASSUMPTIONS as well): 
The pathways are independent of each other, other than radon and the air pathway, and that it is appropriate to calculate a separte sum-of-fractions for each pathway.

Each of the pathways is independent of the others. In fact, the air and radon pathways are independent. DOE 435.1 makes this clear in the statement of the air pathway performance objective: "Dose to representative members of the public via the air pathway shall not exceed $10 \mathrm{mrem}(0.10 \mathrm{mSv})$ in a year total effective dose equivalent, excluding the dose from radon and its progeny."

Section 4 of the document (second paragraph, last two sentences) should be revised to reflect this.

Given the uncertainty in assumptions, comment on the selection of time slices for future work.

Future work should focus on each of the disposal units and time slices should be established based on the timing of doses and/or concentrations for each of the units.

Comment on any additional capabilities that the user may require.

Further work should develop, for each disposal unit, the potential maximum benefit of tracking sums-of-fractions separately for each performance objective and within performance objectives (e.g., different intruder scenarios and different times for the groundwater and air pathways).

Check that the report is presented in a logical manner that is not unduly complicated

The report is presented in a logical manner and is not unduly complicated.

Check that the report accomplished its purpose.

The report accomplished its purpose.

I have a few minor editiorial comments that should be considered.

In Section 2, in the third paragraph, in the first sentence, in the parenthetical statement, the person exposed in the residential or agricultural scenarios is not a member of the public, rather, the person is a hypothetical inadvertent intruder). The statement should be revised to read: "e.g., the intruder during a residential scenario at 100 years is not the same person as that during an agricultural scenario at 700 years".

The titles for Figures 1,2, and 3 should be revised to have the word "hypothetical" to modify that which is being plotted rather than the plot.

\section{EImer}

\section{Comment Resolutions for E. L. Wilhite}

Text revised to match comments. 
16

WSRC-TR-2002-00430

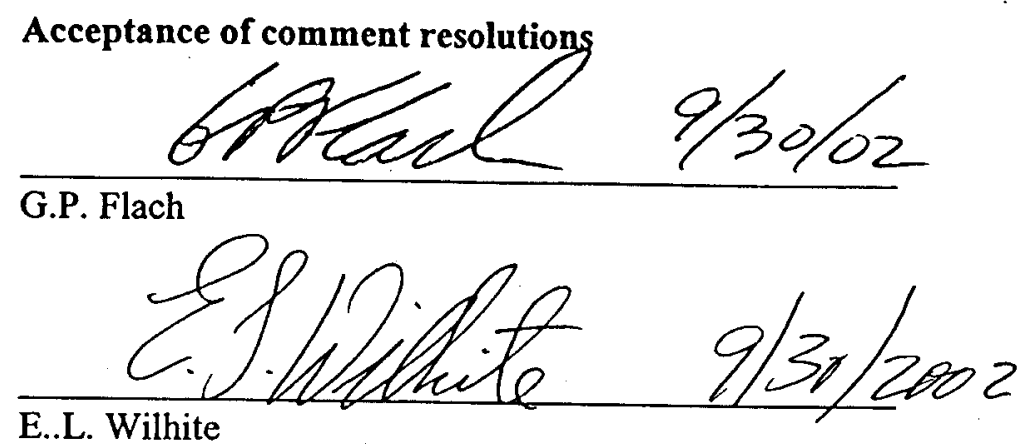

E..L. Wilhite

Rev. 0

September 30, 2002 